$14^{\text {th }}$ Conf. Agric. Develop. Res., Fac. of Agric.,

Ain Shams Univ., March, 2019, Cairo, Egypt

Special Issue, 27(1), 185 - 192, 2019

Website: http://strategy-plan.asu.edu.eg/AUJASCI/

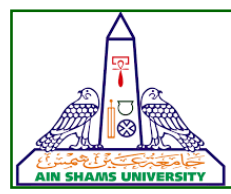

185

\title{
BIOCHEMICAL THEREBY OF MICROORGANISMS CONTAMINATED PRO- DUCTION LINE FOR SOME PRODUCT FOODS USING Olea europaea LEAVES EXTRACT
}

\author{
Saadony H.A. ${ }^{1}$, El Dougdoug K.A. ${ }^{1}$, Abou Hadid A.F. ${ }^{2}$ and Thabet S.D. ${ }^{3}$
}

[17]

1. Agric. Microbiology Dept., Fac. of Agric., Ain Shams Univ., P.O. Box 68 Hadyek Shoubra11241, Cairo, Egypt

2. Horticulture Dept., Fac. of Agric., Ain Shams Univ., P.O. Box 68 Hadyek Shoubra 11241, Cairo, Egypt

3. Quality Assurance, Research and Development Sector Elrashidi El mizan Confectionary, $6^{\text {th }}$ October City, Giza, Egypt

*Corresponding author: hithamabdelhleem@gmail.com

\begin{abstract}
The aim of this work was to investigate the antibacterial activity of aqueous and Ethanolic Extracts of Olive Leaves against pathogenic bacteria isolated from raw material, production line and lines and worker swaps samples. These samples were collected from different factories at Dec.2017 to Feb.2018 in egypt. The bacteria were isolated and identified as E.coli, Staphylococcus arueus and Salmonella typhimrium. The dried of leaves olive was extracted by water and ethanol. The antibacterial activity was determined by Disc diffusion assay and Minimum Inhibitory Concentration (MIC) determined. The extracts were found to be effective inhibitory against all the bacterial isolated, but they were effective inhibitory against Gram-positive more than Gram-negative bacteria. The maximum inhibitory zone was noted against Staph.aureus (24 mm), Salmonella typhimrium $(18 \mathrm{~mm})$ and E.coli (19.8). The MIC observed from the aqueous and ethanolic leaf extract is $50-60 \mathrm{mg} / \mathrm{ml}$ and 30 $60 \mathrm{mg} / \mathrm{ml}$ respectively for E.coli, Staphylococcus arueus and Salmonella typhimrium.
\end{abstract}

Keywords: Antibacterial activity, Aqueous extracts, ethanolic extracts, Olea europaea L.

\section{INTRODUCTION}

Everyone faces the risk of contracting a foodborne illness simply because everyone eats. The World Health Organization (WHO) defines 'Food Safety' as the assurance that, food will not cause harm to the consumer when prepared and/or eaten in accordance with its intended use. Furthermore 'Food Hygiene' is defined, as all the measures necessary to ensure the safety, soundness and wholesomeness of food at all stages from its production or manufacture until its final consumption (WHO, 2010).

The following microorganisms, Staphylococcus aureus, Salmonella spp and Escherichia coli, and their connection to processing hygiene and food handling practices will be included frequent causes of food poisoning in developing countries. (Marriott and Gravani, 2006).

Now a days, the most commonly used commercial preservatives in the food industry. Although the chemical preservatives, synthetic and semi synthetic, have been widely accepted in the modern era, the undesirable side effects cannot be neglected. With the increasing demand for food safety and health standards, consumers have become more concerned about the presence of chemical residues in the food products. So research on safe plant-derived compounds with antimicrobial activity against foodborne pathogens is vital. Use of natural compounds to reduce foodborne pathogens is gaining popularity worldwide. (Ravishankar et al 2008)

Plant extracts with antimicrobial activity offer a promising alternative to the synthetic preservatives used in food products (Dorman and Deans, 2000).

Recently, people have given more emphasis on the research of such next generation food packag- 
ing materials derived from natural plants with antimicrobial activity. Considering the consumers' demand for chemical preservative-free food products, food manufacturers are now using naturally derived antimicrobial agents to replace the traditional chemical ones. There are many advantages to using natural plants as antimicrobial agents: firstly, it is cheap especially for use in underdeveloped nations with little access to expensive western medicines; secondly, natural spice without any chemical synthetic products should be safer and have fewer side effects; thirdly, it is safe to the environment. Thus, it is possible and effective to use these natural plant extracts onfood preservation in order to extend the shelf life of products (Abdallah, 2011).

\section{MATERIALS AND METHODS}

\section{Raw material samples collection}

During December 2017 and February 2018, a total of 40 raw material samples (10 sesame, 10 tomato fruits, 10 coca, 10 strawberry) , 60 production lines steps samples (10 sesame after wash with tap water, 10 sesame after heat treatment, 10 tomato fruits after wash with tap water, 10 tomato juice after heat treatment, 10 strawberry fruits after wash with tap water, 10 straw berry fruits after heat treatment) and 90 cotton swaps samples from production line and worker (10 sesame production line, 20 worker swap from sesame production line, 10 tomato production line, 20 worker swap from tomato production line, 10 jam production line. 20 worker swap from jam production line) were randomly collected from three different factories in Egypt.

\section{Purification and identification of bacterial iso- lates}

Bacterial colonies obtained from all cultured on selective media for E.coli vilot red bile lactose agar, staph.aureus Baird parker agar and Salmonella typhimrium Xylose Lysine Deoxycholate agar were chosen and picked up according to variation in culture characteristics and colony formation then purified by streak-plate method on Nutrient agar medium. Pure isolates were maintained on slants of the same medium at $4^{\circ} \mathrm{C}$ for subsequent identification. Almost all microscopically examinations and biochemical testing used for identification were carried out according to Bergys' mnual (2009).

\section{Morphological characters}

Shape of colony, texture and pigmentation production were examined and recorded.

\section{Biochemical reaction}

Gram reaction, Motility, Catalase, Oxidase, Indole production, Nitrate production, Methyl red, Vogus proskauer, Citrate, Urease, Hydrogen sulphide, Starch and Sugar fermentation were examined and recorded.

\section{Aqueous extract preparation}

Olive leaves (Olea europea.L) used in this study were collected from Dept. of Horticulture Fac. of Agric. Ain shams Univ. They were collected in winter (January) and properly prepared for drying process in the day they were collected.The leaves were washed with water to remove impurities such as dust and then dried in an air oven for 3 days at $38^{\circ} \mathrm{C}$. The dried leaves were crushed in electrical grander of powder. Ten grams of powder plant material was extracted in $100 \mathrm{ml}$ of distilled water for $24 \mathrm{~h}$ at low heat not more than $50^{\circ} \mathrm{C}$. then through Whitman No. 1 filter paper and the filtrated was centrifuged at 5000 for $15 \mathrm{~min}$. the supernatant was collected. The procedure was repeated twice and after 6 hour the supernatant was concentrated to make the final volume. The extract was stored at $4^{\circ} \mathrm{C}$ in air tight bottles.

\section{Solvent extraction preparation}

The extraction was done according to Parekh et al (2005). Ten grams of dried and crushed plant material in electrical grinder were extracted with $100 \mathrm{ml}$ of organic solvent (ethanol) kept on rotatory shaker 190-220 rpm for $24 \mathrm{~h}$, then through Whitman No. 1 filter paper and centrifuged at 5000 for $15 \mathrm{~min}$. the supernatant was collected and the solvent was evaporated at $40^{\circ} \mathrm{C}$ by water bath to make the final volume one fifth the original volume. It was stored at $4^{\circ} \mathrm{C}$ in air tight bottles.

\section{Disc diffusion assay}

Impregnated paper discs with crud plant extract were placed on the surface of inoculated agar plates with E.coli, Staph.arueus and Salmonella typhimrium for $24 \mathrm{~h} \mathrm{(4} \mathrm{mm}$ thickness agar layer). The Petri dishes were sealed using para film and left $1 \mathrm{~h}$ in the refrigerator, in order to allow for the diffusion of the active compounds of the crud plants extracts. Negative controls were done using 

foods using Olea europaea leaves extract

sterile distilled water instead of active compounds. Then, plates were incubated at $37^{\circ} \mathrm{C}$ for $24 \mathrm{~h}$. The susceptibility of the bacteria to each extract was estimated by measuring the diameter of the zones of inhibition and recorded values as the average of three replicates (NARMS, 2002).

\section{Minimal inhibitory concentration assay (MIC)}

The extracts that showed antibacterial activity were tested to determine the Minimal Inhibitory Concentration (MIC) for bacterial sample.

The isolated bacteria Staph.aureus, E.coli and Salmonella typhimrium were grown in nutrient broth for $24 \mathrm{hr}$. Then, $200 \mu \mathrm{l}$ of $10^{8} \mathrm{cells} / \mathrm{ml}$ was inoculated in tubes with nutrient broth supplemented with different concentrations $(1-10 \mu / 100 \mu l)$ of tested extracted.

Afterwards $24 \mathrm{hr}$ a $137^{\circ} \mathrm{C}$, the MIC of each sample was determined by measuring the optical density in the spectrophotometer $(620 \mathrm{~nm})$, comparing the sample readout with that was non inoculated nutrient broth. The MICs were determined as the lowest concentration of tested extracted inhibition visible growth of the lasted culture on the agar plate (Mahdi et al 2013).

\section{RESULTS AND DESCUTION}

Contaminated bacterial isolates from raw material, production steps and cotton swaps.

Contaminated bacteria isolated from collected samples were summarized in Table (1) showed the proportional distribution of foodborne bacterial isolates recovered or found in associated with raw materials, production line and cotton swaps

The total isolates of $\boldsymbol{E}$. coli (87) where (30), (36) and (21) isolates in raw material, production line steps and cotton swaps samples Respectively.

Table 1. Incidence of foodborne bacterial isolates from raw material, Production steps and cotton swap samples.

\begin{tabular}{|cccc|}
\hline \multirow{2}{*}{ Product type } & \multicolumn{3}{c|}{ Bacterial isolates } \\
\cline { 2 - 4 } & E.coli & Staph.aureus & $\begin{array}{c}\text { S.typhiumriu } \\
m\end{array}$ \\
\hline $\begin{array}{c}\text { Raw material } \\
\text { Production } \\
\text { steps }\end{array}$ & $30 / 40$ & $30 / 40$ & $23 / 40$ \\
Cotton swaps & $36 / 60$ & $32 / 60$ & $27 / 60$ \\
\hline Total & $87 / 90$ & $28 / 90$ & $0 / 90$ \\
\hline
\end{tabular}

Staph. aureus (90) isolates were (30), (32) and (28) isolates in raw material, production line steps and cotton swaps samples respectively.
Salmonella (50) isolates with (23) and (27) isolates in raw material and production steps and cotton swaps samples respectively.

The results showed that samples contaminated with staph.aureus more than E.coli and Salmonella typhimrium.

\section{Identification of bacterial isolates}

In the present work, the bacterial Isolates contaminated raw material, production line and cotton swaps samples were taken to be identified according to their morphological, cultural characteristics and consumption of broth manual some biochemical tests in (Tables 2, 3) according to (Bergey's manual, 2009).

\section{Morphological and biochemical identification}

The results of morphological and biochemical characteristics of bacterial isolates were given in Table (2) and Table (3). The identified bacterial isolates from all collected samples were belonging to two main bacterial families ( Enterobactericeae and Staphylococcaceae).

In the present study the isolated E.coli organism fermented mannose, lactose, sucrose and mannitol with the production acid and glocouse production both of acid and gas. Results of Methyl Red, Nitrate, Catalase and Indole test of the E. coli isolates were positive as reported by (Buxton and Fraser 1977). Also Voges-Proskauer, Coagulase, Oxidase, Urease, Starch hydrolysis, $\mathrm{H}_{2} \mathrm{~S}$ production and Citrate utilization test of the E.coli were negative. In Gram's staining, the morphology of the isolated bacteria exhibited, small rod shape,smooth and low convex, the motility test were positive and the $\mathrm{O}_{2}$ requirements were facultative anaerobic. Gram negative bacilli which was supported by several authors (Buxton and Fraser, 1977).

In the present study the isolated Salmonella tphimurium organism fermented mannose, glucose and sucrose with the production acid. Results of Methyl Red, Nitrate, Catalase, and $\mathrm{H}_{2} \mathrm{~S}$ production test of the Salmonella isolates were positive as reported by (WHO, 2007) Also Urease, indole, Coagulase, Voges-Proskauer, Oxidase, ,Starch hydrolysis and Citrate utilization test of the Salmonella were negative. In Gram's staining, the morphology of the isolated bacteria exhibited, small rod shape,smooth and low convex, the motility test were positive and the $\mathrm{O} 2$ requirements were facultative anaerobic. Gram negative bacilli which was supported by several authors (WHO, 2007). 
In the present study the isolated Staphylococcus aureus organism fermented mannose, Mannitol, Lactose glucose and sucrose with the production acid. Results of Methyl Red, Nitrate ,Catalase and Coagulase test of the Staphylococcus isolates were positive as reported by (Habib et al 2015) Also Urease, $\mathrm{H}_{2} \mathrm{~S}$ production, Voges-Proskauer, Oxidase, ,Starch hydrolysis, indole and Citrate utilization test of the Staphylococcus were negative. In Gram's staining, the morphology of the isolated bacteria exhibited, small rod shape,smooth and low convex, the motility test were positive and the $\mathrm{O} 2$ requirements were facultative anaerobic. Gram negative bacilli which was supported by several authors ((Habib et al 2014).

Table 2. Showed tha morphological characteristics of bacterial

\begin{tabular}{|c|c|c|c|}
\hline Test & E.coli & Staph. aureus & Salmonella \\
\hline \multicolumn{4}{|c|}{ Morphological characteristics } \\
\hline $\begin{array}{l}\text { Shape of } \\
\text { colony }\end{array}$ & $\begin{array}{l}\text { Low convex, } \\
\text { entire }\end{array}$ & $\begin{array}{l}\text { Raised, circular, } \\
\text { entire }\end{array}$ & $\begin{array}{l}\text { Low convex, } \\
\text { entire }\end{array}$ \\
\hline Texture & Smooth & Smooth & Smooth \\
\hline Pigmentation & - & Golden yellow & - \\
\hline Motility & + & - & + \\
\hline $\begin{array}{l}\mathrm{O} 2 \text { require- } \\
\text { ments }\end{array}$ & $\begin{array}{c}\text { F. } \\
\text { Anaerobic }\end{array}$ & $\begin{array}{c}\text { F. } \\
\text { Anaerobic }\end{array}$ & $\begin{array}{c}\text { F. } \\
\text { Anaerobic }\end{array}$ \\
\hline \multicolumn{4}{|c|}{ Microscopic examination } \\
\hline Gram reaction & - & + & - \\
\hline Cell shape & $\begin{array}{l}\text { Rods singly or in } \\
\text { pairs }\end{array}$ & $\begin{array}{c}\text { Cocci in clusters } \\
\text { \& pairs }\end{array}$ & $\begin{array}{l}\text { Rods singly or in } \\
\text { pairs }\end{array}$ \\
\hline
\end{tabular}

Table 3. showed the Biochemical characteristics of bacterial isolates.

\begin{tabular}{|c|c|c|c|}
\hline Test & E.coli & $\begin{array}{l}\text { Staph. } \\
\text { aureus }\end{array}$ & Salmonella \\
\hline Catalase & + & + & + \\
\hline Coagulase & - & + & - \\
\hline Oxidase & - & - & - \\
\hline Urease & - & + & - \\
\hline Starch hydrolysis & - & - & - \\
\hline $\mathrm{H}_{2} \mathrm{~S}$ production & - & + & + \\
\hline $\begin{array}{c}\text { Hemolysis on blood } \\
\text { agar }\end{array}$ & Gamma & Beta & Alpha \\
\hline Nitrate reduction & + & + & + \\
\hline Indole formation & + & - & - \\
\hline Methyl red & + & + & + \\
\hline Voges-Proskauer & - & - & - \\
\hline Citrate utilization & - & + & - \\
\hline \multicolumn{4}{|c|}{ Fermentation of sugar } \\
\hline D-glucose & $\mathbf{A} / \mathbf{G}$ & A/- & A/- \\
\hline Sucrose & $-/-$ & $A /-$ & $-1-$ \\
\hline Mannose & $A /-$ & A/- & $A /-$ \\
\hline Lactose & $A /-$ & $A /-$ & $-/-$ \\
\hline Mannitol & A/- & $A /-$ & $-/-$ \\
\hline
\end{tabular}

$\mathrm{A} / \mathrm{G}=\mathrm{acid} / \mathrm{gas} ;(+)=$ positive; $(-)$ =negative

Table 4. showed the antimicrobial activity of the crude ethanol plants extract against bacteria isolated.

\begin{tabular}{|c|c|c|c|}
\hline Olive leaves Extract & E.coli & Staph.arueus & Salmonella \\
\hline \multirow{2}{*}{$\begin{array}{c}\text { Ethanolic } \\
\text { Extract }\end{array}$} & & & \\
& $21.2 \pm 0.36$ & $24 \pm 0.34$ & $19.85 \pm 0.56$ \\
\hline & & & \\
Aqueous extract & & & \\
& & & \\
& & & \\
& & & \\
\end{tabular}

Anti bacterial activity of used aqueous olive extracts

Aqueous olive leaves extract evaluated for antibacterial activity to inhibit pathogenic bacteria, for find a good alternative used in food industry.

The results in (Table 4) of the clear zones diameter of inhibition for pathogenic bacteria
The data given in Table (4) that, E.coli variable sensitivity to the used olive aqueous and ethanolic leaves extracts with average diameter and standard error of inhibition zones, 17.33 \pm 0.83 $(\mathrm{mm})$ and $23.33 \pm 0.83(\mathrm{~mm})$ respectively.

The data given in Table (4) that, staph.aureus variable sensitivity to the used olive aqueous and ethanolic extracts with average diameter and 

foods using Olea europaea leaves extract

standard error of inhibition zones, $19.45 \pm 0.54$ $(\mathrm{mm})$ and $24 \pm 0.34(\mathrm{~mm})$ respectively.

The data given in Table (4) that, salmonella typhimurium variable sensitivity to the used olive aqueous and ethanolic leaves extracts with average diameter and standard error of inhibition zones, 13.6 $\pm 0.83(\mathrm{~mm})$ and 19.85 $\pm 0.56(\mathrm{~mm})$ respectively.

The olive leaf extracts showed good inhibitory effects on pathogenic bacteria. Many studies confirm positive role of olive leaf in inhibitory pathogenic bacteria.( Markin et al 2003) also reported that water extract of olive leaf with a concentration of $0.6 \%(\mathrm{w} / \mathrm{v})$ killed E.coli, $P$. aeruginosa, $S$. aureus and $K$. pneumoniain.

Difference in the phenolic compounds distribution strongly affects the functionality of the extracts such as antimicrobial activity.

Although the individual phenolic compounds in olive leaf extract may show strong in vitro activities, the antioxidant and antimicrobial activities of combined phenolics showed similar or better effects than the individual phenolics (Lee at al 2010).

Turhan (2009) investigated the effect of different solvents used in extraction on the antimicrobial activity of OLEs against Staphylococcus aureus by paper disc bioassay. It was reported that the concentration of $129 \mathrm{mg} / \mathrm{mL}$ olive leaf water extract showed the highest inhibitory effect on S.aureus and followed by chloroform/ethanol and chloroform/methanol extracts.

In other words, flavonoids and phenolic compounds obtained from olive leaf are known to have diverse biological activities and may also be responsible for the pharmacological actions of olive leaf or, at least synergistically reinforcing those actions (Abaza et al 2007).

\section{Minimum Inhibitory Concentrations (MICs) of total Olive leaves extract by spectrophotome- ter}

The results were illustrated in Fig. (1) showed the (MICs) values of aqueous extract of Olea europaea the growth of tested contaminated bacteria.

In the presence of aqueous extract of Olea europaea at lowest concentration $50 \mathrm{mg} / \mathrm{ml}$ got the highest inhibition for Salmonella and staphylococcus arueus. While E.coli required more milligram $60 \mathrm{mg} / \mathrm{ml}$ of aqueous extract for highest inhibition.

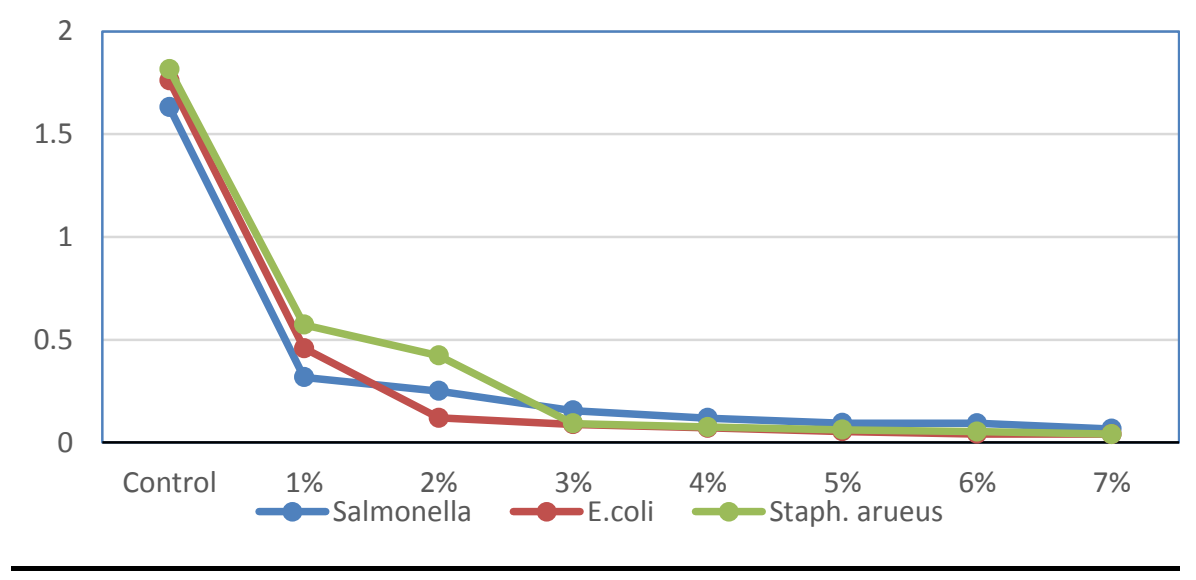

Fig. 1. Curve gram Showing MICs $(\mathrm{mg} / \mathrm{ml})$ of aqueous extract of Olea europaea against bacterial isolates.

The results were illustrated in Fig. (2) showed the (MICs) values of ethanol extract of Olea europaea the growth of tested foodborne associated bacteria.

In the presence of ethanol extract of Olea europaea at lowest concentration $30 \mathrm{mg} / \mathrm{ml}$ and 50 $\mathrm{mg} / \mathrm{ml}$ got the highest inhibition for staphylococcus arueus and salmonella typhimruim respective- ly. While E.coli required more milligram $60 \mathrm{mg} / \mathrm{ml}$ of ethanol extract for highest

The antibacterial activity was determined by Disc diffusion assay and Minimum Inhibitory Concentration (MIC) and Minimum have been determined. The extracts were found to be effective against all the bacterial strains, but they were effective against Gram-positive more than Gramnegative bacteria 
In the presence of ethanol extract of Olea europaea at lowest concentration $30 \mathrm{mg} / \mathrm{ml}$ and 50 $\mathrm{mg} / \mathrm{ml}$ got the highest inhibition for staphylococcus arueus and salmonella typhimruim respectively. While $E$. coli required more milligram $60 \mathrm{mg} / \mathrm{ml}$ of ethanol extract for highest

The antibacterial activity was determined by Disc diffusion assay and Minimum Inhibitory Concentration (MIC) and Minimum have been deter- mined. The extracts were found to be effective against all the bacterial strains, but they were effective against Gram-positive more than Gramnegative bacteria

Lahdibi Sahraoui et al (2017) observed the MIC from the aqueous and methanolic olive leaf extract is $12.5-50 \mu \mathrm{g} / \mathrm{ml}$ and $1.56-12.5 \mu \mathrm{g} / \mathrm{ml}$ respectively.

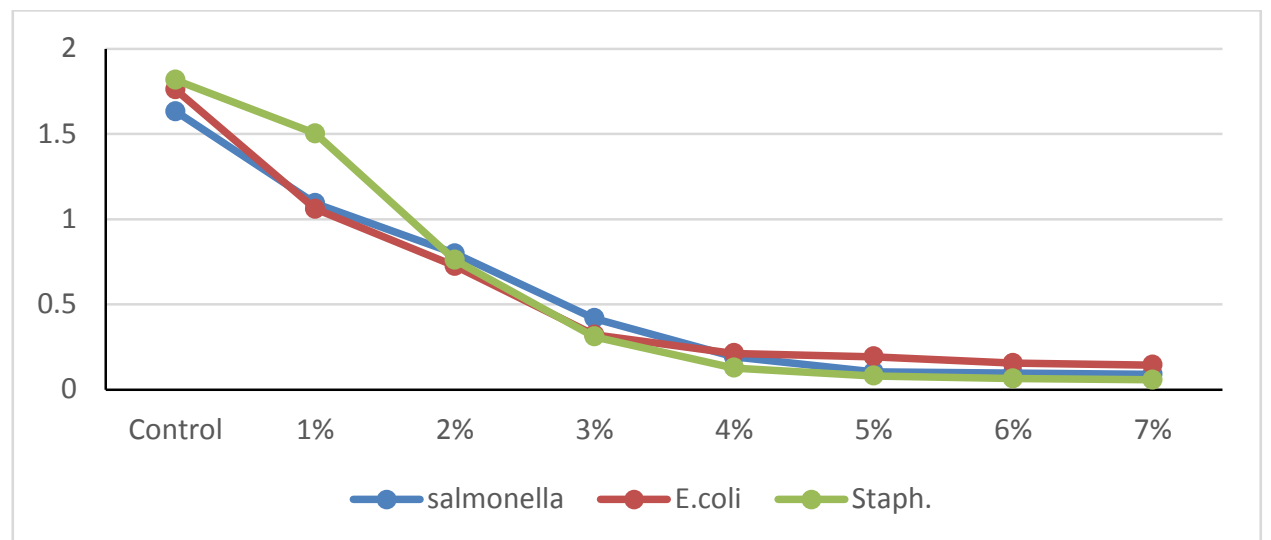

Fig. 2. Curve gram Showing MICs $(\mathrm{mg} / \mathrm{ml}$ ) of ethanol extract of Olea europaea against bacterial isolates.

\section{REFERENCES}

Abaza L., Talorete T.P.N., Yamada P., Kurita Y., Zarrouk, M. and Isoda H., 2007. Induction of Growth Inhibition and Differentiation of Human Leukemia HL-60 Cells by a Tunisian Gerboui Olive Leaf Extract. Biosci. Biotechnol. and Biochem. 71, 1306-1312.

Abdallah, E.M. 2011. Plants. An alternative source for antimicrobials. J. Appl. Pharm. Sci., 1 (6), 16-20.

Bergey's Manual. 2009. Bergey's manual of systematic bacteriology. Sneath, P.H.A., Mair, N.S., Sharpe, M. Elizabeth and Holt, J.G. (eds.) Pub. Williams and Wilkins, 2605.

Buxton A. and G. Fraser. 1977. Escherichia coli. In: Animal Microbiology. Vol. 1, Blackwell Scientific Publications, London, pp. 78-80.

Dorman, H.J.D. and Deans S.G. 2000. Antimicrobial agents from plants: antimicrobial activity of plant volatile oils. J. Appl. Microbiol., 88 (2), 308-316.

Habib F., Rehmatullah R., Naeemullah D., Abdul Latif B., Rehana S.B., Ahmed T., A. Nazia, Shakeel A.L., Ali G.B. and Muhammad S. 2015. Morphological and Cultural Characterization of Staphylococcus Aureus Isolated from
Different Animal Species Environ. Biol. Sci., 5(2), 15-26.

Lahdibi Sahraoui H., El-Berny H.; El Karkour M., Quasmaoui H., Charof R. and Mennane Z. 2017. Antibacterial Activity of Aqueous and Methanolic Extracts of Olive (Olea europaea L.) Leaves Collected from Different Regions in Morocco. Der Pharma Chemica, 9(13), 118-124

Lee, O.H. and Lee B.Y. 2010. Antioxidant and Antimicrobial Activities of Individual and Combined Phenolics in Olea europea Leaf Extract. Bio. Tech., 101, 3751- 3754.

Mahdi, K.M., Mohammad M., Mohamma R. and Mansour, G. 2013. Study on antibacterial effect of thyme and peppermintaqueous extracts on Staphylococcus aureus and Escherichia coli strains causing mastitis in Camels. Int. J. Trad. and Herbal Medicine, 1(4), 112-115.

Markin, D., Duek L. and Berdicevsky I. 2003. In vitro Antimicrobial Activity of Olive Leaves. Mycoses, 46, 132-136.

Marriott N.G. and Gravani R.B. 2006. Principles of Food Sanitation. $5^{\text {th }}$ Ed. 10, 190. United States: Springer.

NARMS. 2002. National Antimicrobial Resistance Monitoring System, Enteric Bacteria. CDC, USA, pp. 18-24. 

foods using Olea europaea leaves extract

Parekh, J.I., Karathia N. and Chanda S. 2006. Evaluation of antibacterial activity and phytochemical analysis of Bauhinia variegata L. bark. Afr. J. Biomed. Res., 98, 213-216.

Ravishankar, S., Zhu L., Law B., Joens L. and Friedman M. 2008. Plant-derivedcompounds inactivate antibiotic-resistant Campylobacter jejunistr-ains. J. Food Prot. 71 (6), 1145-1149.
Turhan K.N. 2009. Production and characterization of antimicrobial polylactic acid and methylcellulose-polylactic acid films. The Scientific and Technological Research Council of Turkey, Turkey. Project No. 1070234.

WHO. 2007. Global Salm-Surv. Laboratory Protocol: Isolation of Salmonella. $5^{\text {th }}$ Ed., pp. 18. 

المؤتمر الرابع عشر لبحوث التنمية الزراعية،

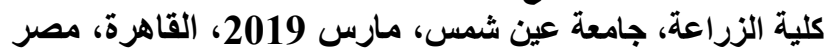

مجلا(27)، عدد (1)، عدد خاص مارس، مارس، 192-185، 2019

\section{المعالجة البيوكيميائية للميكرويات الملوثة لخط إنتاج الأغذية المصنعة \\ بإستخدام مستخلصات الزيتون}

[17]

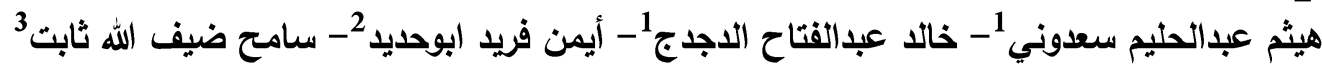

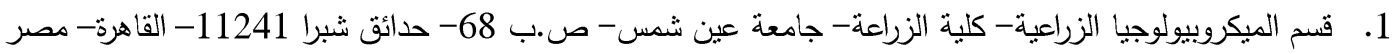

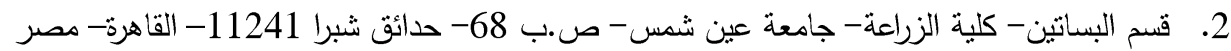

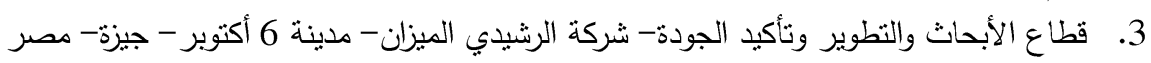

*Corresponding author: hithamabdelhleem@gmail.com

Received 12 February, 2019,

Accepted 25 March, 2019

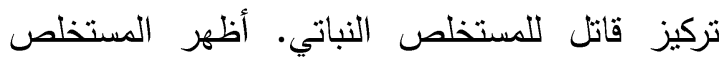

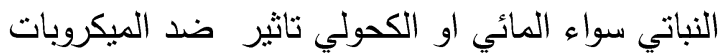

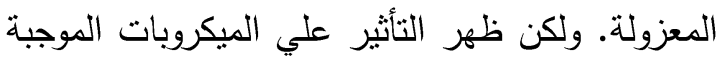
لجرام اكثر من الميكروبات السالبة لجرام. حيث ظهرت البكريت اكبر هالة تحلل علي الميكروبات العنقودية بقطر 24

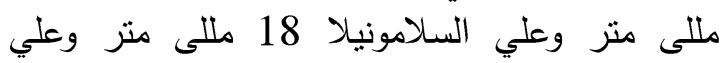
الايكولاي 19.8 مللى متر • واظهرت النتائج ان افضل الفل

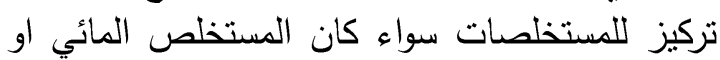

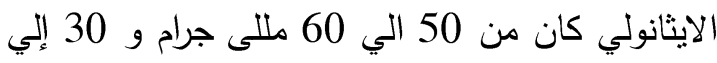

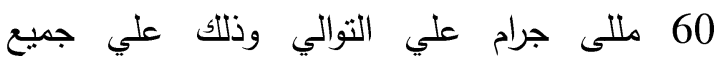
الميكروبات المعزولة.

الكلمات الدالة: مضادات البكتريا، المستخلص المائي، المستخلص الايثانولي، الزيتون

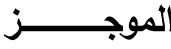

يهدف البحث إلى دراسة تاثير مستخلص أوراق

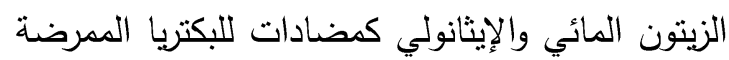
الملوثة لخطوط الإنتاج في بعض الإناني كلئ المصانع. حيث تم

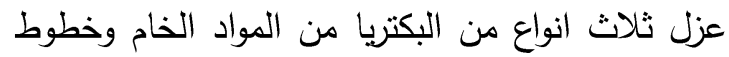

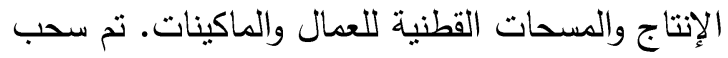
العينات من مصانع مختلفة بمهورية مصر العربية ما بين شهر ديسمبر 2017 إلى شهر فبراير 2018.

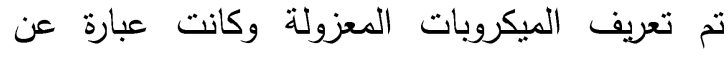

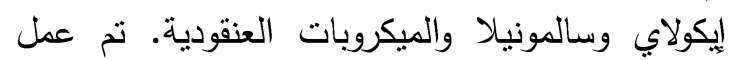
مستخلصات ورق الزيتون بواسطة المياه والكحول

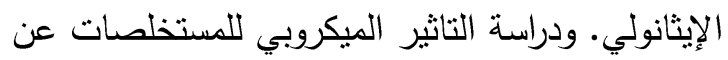

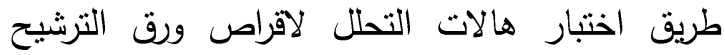

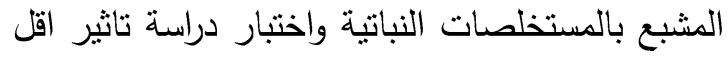

